\title{
Fisiologia da Contração Muscular
}

\section{Physiology of muscular contraction}

\section{Alice Teixeira Ferreira}

Escola Paulista de Medicina / Universidade Federal de São Paulo - UNIFESP.

O músculo esquelético é um órgão especializado na transformação de energia química em movimento(energia mecânica), desenvolvido para otimizar esta função utilizando um conjunto bem ordenado de proteínas relacionadas com o movimento.

Os 600 músculos esqueléticos do corpo humano são compostos de centenas à centenas de milhares de células alongadas, multinucleadas chamadas fibras musculares. Cada fibra contem as proteínas contrateis Miosina e Actina, que compõe os filamentos grossos e finos respectivamente, que estão dispostos paralelamente nas miofibrilas que compõe as fibras. As miofibrilas estão também paralelamente arranjadas e apresentam um padrão de bandas escuras e claras dispostas em série, que dão o caráter de estrias às fibras de tais músculos. Esta aparência estriada característica da miofibrila observável na microscopia de luz decorre da birrefringência diferente das proteínas contrateis:a banda clara, chamada banda-I, é devida a isotropia (I) da região da miofibrila dada pelos filamentos finos e a banda-A, devida a sua anisotropia(A), constituída pelos filamentos grossos intercalados aos finos. Os limites laterais da unidade contrátil chamada de sarcômero são dados pelos discos Z, constituídos por alfaActinina, onde se ancoram os filamentos finos, a Tinina e a Nebulina. Na microscopia de luz o sarcômero é delimitado por duas linhas $\mathrm{Z}$ e contem duas banda-I e uma banda -A central separando-as.

A contração é definida como a ativação das fibras musculares com a tendência destas

se encurtarem. Ocorre quando o cálcio citosólico $\left(\left[\mathrm{Ca}^{2+}\right]_{\mathrm{i}}\right)$ aumenta disparando uma série de eventos moleculares que levam à interação entre miosina e actina, ocorrendo o deslizamento desta última sobre os filamentos grosso e o encurtamento dos sarcômeros em série.

\section{Acoplamento Excitação-Contração}


A despolarização do sarcolema da fibra muscular esquelética se propaga da superfície para o interior da fibra através dos túbulos-T. Junto aos túbulos se encontram as cisternas do retículo sarcoplasmático formando com o túbulo $\mathrm{T}$ uma estrutura denominada Tríade. Na membrana dos túbulos se encontram proteínas integrais que a transfixam chamadas Proteínas DHP por terem afinidade por dihidropiridina, substância inibidora da abertura de seus canais cálcio-seletivos intrínsecos. A despolarização do túbulo $\mathrm{T}$ induz a alteração da conformação das proteínas DHP. Esta modificação é transmitida aos podócitos que se encontram em contacto com tais proteínas. Os podócitos são projeções citoplasmáticas de proteínas integrais da membrana do retículo sarcoplasmático, chamadas Proteínas Receptoras de Rianodina, cuja isoforma na musculatura esquelética é abreviada por RyR1. Estas proteínas se encontram concentradas na face da cisterna em contacto com o túbulo $\mathrm{T}$ e contem canais intrínsecos seletivos ao cálcio. Uma vez ativado o RyR1 pela alteração de conformação da proteína DHP induzida pela despolarização que atingiu os túbulos $\mathrm{T}$, os seus canais são abertos efluindo cálcio do retículo para o citoplasma da fibra muscular. A mudança de conformação de RyR1 se transmite à outra proteína ligada à este receptor, chamada Triadina. Esta última mobiliza o cálcio ligado á Parvalbumina, Calsequestrina e Reticulina, todas encontradas no interior do retículo sarcoplamático e em contacto entre si, que liberam mais cálcio. Este íon sae pelo canal de RyR1, que se encontra aberto. contribuindo para o maior aumento do cálcio citosólico.

O filamento grosso é constituído por moléculas de miosina, dispostas ordenadamente. Cada molécula de miosina é constituída por dupla hélices enroladas entre si e numa das extremidades se encontram duas cabeças globulares. $\mathrm{O}$ seu arranjo é regular de tal maneira que as cabeças se dispõe de maneira helicoidal, separadas por 14,5 nm. Existem 294 moléculas por filamento grosso. Como as cabeças têm atividade ATPásica existem 588 sítios com tal propriedade. O filamento grosso se encontra no centro de um hexágono em cujos vértices se encontram dispostos os filamentos finos.

O filamento fino é constituído por actina filamentosa (Act-F), que é formada por dois filamentos de actina globular (Act-G) entrelaçados, por Tropomiosinas fixadas sobre Act-F por Tropnina em intervalos de 7 Act-Gs. A Troponina é composta de três subunidades chamadas Troponina C (que tem afinidade por Cálcio, TnC), Troponina I (TnI) e Troponina T $(\mathbf{T n T})$. A subunidade TnI está ligada a uma das Act-Gs e a subunidade TnT à Tropomiosina e a TnC ligada a estas duas subunidades.O cálcio ao se ligar à TnC faz com que o conjunto modifique a sua conformação desligando TnI da AcT-G/F , simultaneamente 
deslocado a Tropomiosina, expondo os sítios das Act-Gs permitindo a interação com as projeções das cadeias de miosina, chamadas de cabeça, que constituem o filamento grosso. Numa reação que envolve a hidrólise de ATP, tem-se o deslizamento dos fillamentos finos em relação aos filamentos grossos , com conseqüente encurtamento dos sarcômeros (aproximação dos discos Z), com a produção de força ao longo da miofibrila.

A formação de pontes entre Act-F e miosina é reversível, na presença de ATP, ocorrendo com a modificação da posição da cabeça da miosina de 45 à 90 graus, tendo um deslocamento de 100 Angstrons. A energia deste processo provem da hidrólise de ATP, liberando ADP e Pi ( processo de transdução de energia). Pouco se sabe sobre este processo, sendo as seguintes perguntas ainda não esclarecidas:

1) quantos sítios de ligação da Act-F estão envolvidos num abalo contrátil?

2) qual parte da cabeça da miosina muda de conformação?

3). As duas cabeças da miosina comportam-se de maneira independente?

\section{Referências}

1. Brian R. MacIntosh. Role of Calcium Sensivity Modulation in Skeletal Muscle Perfomance. News Physiol Sci 2003; 18: 222-225.

2. Clark KA, McElhinny AS, Beckerle MC, Gregorio CC. Striated Muscle Cytoarchicterure: An Intricate Web of Form and Function. Ann Rev Cell Dev Biol 2002; 18: 637-706.

3. Geeves MA, Holmes KC. Structural Mechanism of Muscle Contraction. Ann Rev Biochem 1999; 68: 687-728.

4. Brooks SV. Current Topics for Teaching Skeletal Muscle Physiology. Adv Physiol Educ 2003; 27: 171-172. 